\title{
Sustainable benchmarking of supply chains: the case of the food industry
}

\author{
Natalia Yakovleva ${ }^{\mathrm{a}}$, Joseph Sarkis ${ }^{\mathrm{b}}$ and Thomas Sloan ${ }^{\mathrm{c} *}$ \\ ${ }^{a}$ BRASS Research Centre, Cardiff University, Cardiff, UK; ${ }^{b}$ Graduate School of Management, \\ Clark University, Worcester, MA, USA ; ${ }^{c}$ College of Management, University of Massachusetts Lowell, \\ Lowell, MA, USA
}

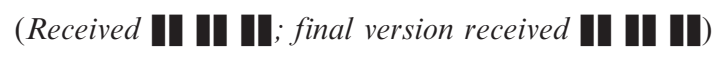

\begin{abstract}
Long-term organisational viability and competitiveness should not be evaluated solely in terms of financial measures. Investors, policy makers and other stakeholders increasingly seek to evaluate performance with respect to sustainability - the environmental, social and economic performance of an organisation. But measuring and improving the sustainability performance of supply chains is challenging. Using one of the world's most critical supply chains, the food supply chain, we introduce and apply a multi-stage procedure to help analytically evaluate supply chains' sustainability performance. The method involves development of sustainability indicators, data collection, data transformation using rescaling and determining of importance ratings using the Analytical Hierarchy Process (AHP). The proposed methodology demonstrates how quantitative statistical data can be combined with expert opinion to construct an overall index of sustainability. Stakeholders can use the index to evaluate and guide sustainability performance of supply chains. Strengths and opportunities, as well as limitations of the methodology are discussed, and sensitivity analysis is performed.
\end{abstract}

Keywords: sustainability; supply chain management, performance measurement, analytic hierarchy process, food supply chain

\section{Introduction}

There is a growing desire in business and industry to expand the boundaries of performance benchmarking beyond financial parameters and demonstrate contribution towards sustainability. Corporate stakeholders increasingly demand organisations to consider and account for sustainability implications of operations beyond the organisation and across a supply chain context. Although there are notable developments in the field of sustainability benchmarking to account for lifecycle influences of products and processes, there is still considerable room for tools and methodologies to effectively measure and benchmark multi-dimensional sustainability performance of supply chain operations (New 1997, Kärnä and Heiskanen 1998, Hervani et al. 2005, Seuring and Müeller 2008). One of the major challenges for sustainability benchmarking across supply chains is to account for the multi-dimensional nature of sustainability encompassing economic, social and environmental implications of business and supply chain operations (Bai and Sarkis 2010).

The current paper develops a methodology to measure and benchmark sustainability performance of supply chains through an integrated index that is achieved through application of the Analytical Hierarchy Process (AHP). The present paper addresses several major aspects of sustainability benchmarking: first - by developing indicators that reflect three dimensions of sustainability - environmental, social and economic following a concept of triplebottom line; second - by applying sustainability indicators to various supply chain stages from production to retail; third - by incorporating strategic sustainability target setting through scaling indicators according to desirability of sustainability performance; fourth - by determining relative importance between indicators across sustainability dimensions and supply chain stages.

The current paper demonstrates the proposed methodology by applying it to benchmarking sustainability of food supply chains. The food supply chain serves as a useful example because sustainability implications of food production and consumption are critical for many food organisations, policy makers and other stakeholders, who are highly concerned with sustainability effects of food supply chain operations (Marsden et al. 1999). The proposed methodology can be used by industry, managers, monitoring and consumers' organisations, and policy makers to

\footnotetext{
*Corresponding author. Email: Thomas_Sloan@uml.edu
}

ISSN 0020-7543 print/ISSN 1366-588X online

(C) 2011 Taylor \& Francis

DOI: $10.1080 / 00207543.2011 .571926$

http://www.informaworld.com 
access and compare sustainability of supply chain operations and review contributions of individual elements within the supply chain towards the overall sustainability index.

The currrent paper starts with the review of literature on benchmarking and sustainability and then provides an overview of sustainability concerns in the food supply chain. We explain our methodology for benchmarking sustainability in the supply chain through detailed exposition of sustainability indicators development and scoring for the food supply chain. The proposed framework is evaluated using data for potato and chicken supply chains in the United Kingdom (UK). Further, we introduce weighting schemes using AHP and describe the results of a sensitivity analysis. Finally, the discussion and conclusions section outlines the implications of the proposed sustainability benchmarking framework and discusses future work.

\section{Benchmarking and sustainability}

Benchmarking is a process of evaluation of organisational products, services, and processes in relation to the best practice (Camp 1995, McNair and Leibfried 1995). The term is often associated with efforts undertaken by individual firms to identify and imitate best practices within their own industry. Benchmarking has been frequently cited as an important tool used for continuous improvement of organisational performance, total quality management and competitive advantage (McNair and Leibfried 1995, Simatupang and Sridharan 2004, Manning et al. 2008). Benchmarking has gained considerable popularity in business and industry (Camp 1995, Zairi and Youssef 1995a, Wever et al. 2007) and has been well reviewed in practitioner-oriented literature (Zairi and Youssef 1995b, 1996, Sarkis 2001a). In this paper, we approach benchmarking as the process of defining operational measures of performance and appraising firms (or supply chains) with respect to selected measures.

Effective benchmarking requires data analysis. Dozens of tools for benchmarking have been developed, they include flowcharts, cause-and-effect diagrams, radar/spider charts and $Z$ charts (Camp 1995), the European Foundation for Quality Management (EFQM) business excellence model, the balanced scorecard, service quality (SERVQUAL) framework, gap analysis, AHP, scatter diagrams (Ahmed and Rafiq 1998), computational geometry (Talluri and Sarkis 2001), data envelopment analysis (DEA) (Zhu 2002) and the Operational Competitiveness Ratings Analysis (OCRA) (Oral 1993, Parkan 1994, Jayanthi et al. 1999). A distinct advantage of AHP among these tools its ability to consider multiple attributes and factors, which is a key characteristic of sustainability measurement, and utilisation of both qualitative and quantitative data, which is highly beneficial when considering sustainability issues (Chan 2003).

\subsection{Supply chain performance measurement}

Benchmarking typically focuses on a single link - or even a single process within a link - rather than the entire supply chain (Shepherd and Gunter 2006). There are significant challenges for performance measurement across supply chains to facilitate benchmarking. For example, Gunasekaran et al. (2001) identify a variety of financial and non-financial metrics that firms can use to evaluate different dimensions of performance at the strategic, tactical, and operational levels. Although this type of work can help to construct standardised measures which may result in improved performance, it does not result in a supply-chain wide measure and does not offer opportunities for benchmarking. Application of AHP to supply chain benchmarking has been a recommended and favoured approach (Min and Galle 1996, Chan, 2003). We follow in that process, and extend it to sustainability.

\subsection{Sustainability benchmarking}

Given new industry pressures, sustainability is placed highly in the agenda of industry and other stakeholders to benchmark supply chain performance. In the current paper we introduce sustainability as part of the triple bottom line concept recommending that firms measure and report their success according to economic, social and environmental performance criteria (Elkington 1997). Although there are examples when the three dimensions of sustainability (economic, social and environmental) have been incorporated to measure supply chain performance (New 1997, Kärnä and Heiskanen 1998, Sarkis 2001b), the majority of frameworks usually evaluate two dimensions of sustainability (economic and environmental) and very rarely embrace all three dimensions (Veleva et al. 2003, Seuring and Müller 2008, Bai and Sarkis 2010). 
There has been an emergent set of investigations related to benchmarking and performance measurement in relation to sustainability (Sarkis 2010). Most of this research, however, is oriented toward improvement of individual firms or processes rather than toward analysis of entire supply chains. There have been attempts to measure sustainability; however, most of these efforts focus on firm- or product-level performance. Furthermore, there is a strong emphasis on environmental performance. Thus, there is a significant need to measure broader sustainability across the supply chain.

\subsection{Benchmarking the food supply chain}

The food supply chain is critically important to society (Fine et al. 1996, Barrett et al. 1999, Marsden et al. 1999). This paper adopts a definition, utilised by the UK Department for Environment, Food and Rural Affairs (DEFRA 2006), of the food supply chain that consists of the stages of agricultural production, food processing, food wholesaling, food retailing and food catering.

Food accounts for a significant share of modern production and consumption and its supply has considerable implications for economic growth, employment, health, development, communities and the natural environment (Marsden et al. 1999, Hinrichs and Lyson 2008, Roth et al. 2008). Growing environmental and ethical concerns about effects of food supply chain on the natural environment have led to an increased pressure from a variety of stakeholders to improve sustainability performance of product lifecycles from 'farm to folk' (Hughes 2001, Courville 2003, Weatherell et al. 2003, Ilbery and Maye 2005).

The food industry was amongst the first to look into aspects of sustainability, including pollution, labour standards, ethics in supplier relations and waste issues (Fritz and Schiefer 2008). Looking at regional, sector and firm levels, various frameworks have been developed to study effects of the food sector - notably, lifecycle sustainability impacts, farm economic costing, food miles, energy accounting in product lifecycles, footprint analysis, mass balance and farm sustainability indicators (Linstead and Ekins 2001, Gerbens-Leenes et al. 2002, Carlsson-Kanayama et al. 2003, Garnett 2003, Heller and Keoleian 2003, Biffaward 2005, Pretty et al. 2005, Collins and Fairchild 2007). These studies have been successful in highlighting problems areas in food production and consumption.

Most importantly, the food sector is constantly innovating with alternative strategies to decrease burdens on the natural environment and improve social and ethical issues in supply chain through various production, marketing, labelling, accreditations schemes and initiatives (Weatherell et al. 2003, Ilbery and Maye 2007). However, no formal modelling approach to benchmarking the sustainability of food supply chains exists.

\section{A methodology for sustainability benchmarking or supply chains}

We propose a formal methodological framework to benchmark supply chains according to sustainability performance that consists of four major stages:

(1) Identification of sustainability indicators.

(2) Raw data gathering and data transformation using performance rescaling.

(3) Data gathering and adjustment using AHP.

(4) Sensitivity analysis of results.

This section outlines the first three stages and the case study section will illustrate the last two stages of the methodology in detail. We use data for general industrial level analysis (e.g. potatoes or flowers or other general agricultural products) rather than for specific organisational product level (e.g. Schvaneveldt 2003). Although

130 strategic information for product and process design practices can be gleaned from product-level benchmarking for improved environmental performance (Boks and Stevels 2003, Wever et al. 2007), we use a higher-level perspective for our analysis for increased cooperation within the industry toward sustainability improvement.

\subsection{Development of sustainability indicators}

The first stage of the framework is to identify a range of indicators to be considered in the sustainability assessment for benchmarking of supply chains. In this paper, we consider stages of agriculture (farming), food processing, food wholesale, food retail and food catering in the assessment of the food supply chain. Our framework aims to 
Table 1. Sustainability indicators for the food supply chain.

\begin{tabular}{llll}
\hline Supply chain stage & Environmental & \multicolumn{1}{c}{ Social } & Economic \\
\hline Agriculture/ & $\bullet$ Energy consumption & $\bullet$ Employment & $\bullet$ Labour productivity \\
Food processing/ & $\bullet$ Water consumption & $\bullet$ Wages & Market concentration \\
Food wholesale/ & $\bullet$ Waste arising & $\bullet$ Employment gender ratio & Import dependency \\
Food retail/ & & & \\
Food catering & & & \\
\hline
\end{tabular}

Source: Adapted from Yakovleva and Flynn (2004).

incorporate three dimensions of sustainability: economic, social, and environmental. Firstly, objectives of sustainable development applicable to the industry level and specifically for the food sector have been selected from the objectives of sustainable development outlined for the industry by United Nations Conference on Sustainable Development (UNCSD 1998) and those stated in Agenda 21 (United Nations 1992). The following objectives have been considered for the assessment: (1) within the economic dimension: promotion of economic growth, encouragement of open and competitive economy, and changing consumption patterns; (2) within the social dimension: creation of productive employment, achieving equality; and (3) within the environmental dimension: reduction of resource use and protection of natural environment. Then, appropriate criteria for measuring the progress towards an objective were selected and followed by the choice of a final indicator. An attempt was made to select indicators that apply to all stages in the food supply chain in order to compare the sustainability performance between the stages. The indicators in this study are purposefully fairly generic, which enables comparison between the stages and between different food products.

For example, the sequence for selection of an indicator within the economic dimension could be demonstrated as

150 follows. Promotion of economic growth is an important objective of sustainable development within the economic dimension. Within industry, it could be measured by productivity. A specific indicator is selected to measure productivity, such as Gross Value Added per worker, data for which are ready available with statistical services. Potential users of this framework may choose industry specific sustainability objectives and indicators that are crucial for demonstrating progress towards sustainable development.

Initially, over 50 indicators were drawn for five stages of the supply chain (Yakovleva and Flynn 2004); however, due to data limitations and to help exemplify the methodology proposed in this paper, a final set of nine indicators is selected for the framework, three per dimension. Thus, we have a total of 45 indicators (nine sustainability indicators for each of the five stages) for the framework, which are reported in Table 1.

\subsection{Data gathering and transformation}

160 The framework in the current study uses data from potato and chicken food supply chains in the UK. Chickens and potatoes represent different production processes within the food supply chain (chicken is the most popular meat category, and potato is the most popular vegetable). The data for these supply chains were collected for 2002 (see Table 2).

\subsubsection{Data gathering}

165 Since we are focusing on UK food supply chains, statistical information is collected from two different organisations within the British Government: DEFRA collects information on the agricultural sector, whereas the Office for National Statistics (ONS) collects information on the production industries including the food sector.

\subsubsection{Data Transformation using Performance Rescaling and Normalisation}

In order to analyse and compare the data for various stages in the supply chain and between two products, the indicators are normalised. The UK economy average or food supply chain average values are used as a benchmark for the development of normalised scores. Indicators are allocated scores on a scale of $1-6$. The 0 score stands for no available information, a score of 1 reflects a low benefit to sustainability and a score of 6 a high level of 
Table 2. Sustainability indicators for the chicken and potato supply chains (data for 2002) ${ }^{1}$.

Stage of the food supply chain/

Dimension of sustainability/Indicators

\begin{tabular}{|c|c|c|c|c|c|}
\hline Agricultural production & Units & Chicken & Potato & Agriculture & $\begin{array}{l}\text { Total UK } \\
\text { economy }\end{array}$ \\
\hline \multicolumn{6}{|l|}{ Economic indicators } \\
\hline Number of enterprises & & 725 & 4,581 & 142,840 & $1,619,195$ \\
\hline Total output & $£^{\prime} 000$ & 821,000 & 544,000 & $15,508,000$ & $1,948,458,000$ \\
\hline Total output & '000 tonnes & 1,202 & 6,663 & $\mathrm{n} / \mathrm{a}$ & $\mathrm{n} / \mathrm{a}$ \\
\hline Output per enterprise & $£ ’ 000$ & 1,132 & 118 & 108 & 1,203 \\
\hline Output per enterprise & '000 tonnes & 1.65 & 1.45 & $\mathrm{n} / \mathrm{a}$ & $\mathrm{n} / \mathrm{a}$ \\
\hline GVA & $£^{\prime} 000$ & $\mathrm{n} / \mathrm{a}$ & $\mathrm{n} / \mathrm{a}$ & $7,137,000$ & $926,275,000$ \\
\hline Labour productivity (GVA per workforce) & $£$ & $\mathrm{n} / \mathrm{a}$ & $\mathrm{n} / \mathrm{a}$ & 12,976 & 35,600 \\
\hline Large enterprises & $\%$ & $12 \%^{2}$ & $16 \%{ }^{3}$ & $14 \%{ }^{4}$ & $2 \% 5$ \\
\hline Imported products vs. domestic & $\%$ & $0.007 \%$ & $9 \%$ & $38 \%$ & $\mathrm{n} / \mathrm{a}$ \\
\hline \multicolumn{6}{|l|}{ Social indicators } \\
\hline Total employment, average per year & people & 9200 & $\mathrm{n} / \mathrm{a}$ & 550,000 & $26,000,000$ \\
\hline Employee per enterprise & people & 12.7 & $\mathrm{n} / \mathrm{a}$ & 3.8 & 16.1 \\
\hline Average gross wages per employee (min) & £per year & $\mathrm{n} / \mathrm{a}$ & $\mathrm{n} / \mathrm{a}$ & $15,735^{6} / 3,467^{7}$ & 21,685 \\
\hline $\begin{array}{l}\text { Male vs. female employment full time } \\
\text { labour }\end{array}$ & $\%$ & $\mathrm{n} / \mathrm{a}$ & $\mathrm{n} / \mathrm{a}$ & $\mathrm{n} / \mathrm{a}$ & $63 \%$ \\
\hline \multicolumn{6}{|l|}{ Environmental indicators } \\
\hline $\begin{array}{l}\text { Purchase of energy for own consumption } \\
\text { per enterprise }\end{array}$ & $£ ’ 000$ & $\mathrm{n} / \mathrm{a}$ & $\mathrm{n} / \mathrm{a}$ & $\mathrm{n} / \mathrm{a}$ & $\mathrm{n} / \mathrm{a}$ \\
\hline $\begin{array}{l}\text { Purchase of water for own consumption per } \\
\text { enterprise }\end{array}$ & $£ ’ 000$ & $\mathrm{n} / \mathrm{a}$ & $\mathrm{n} / \mathrm{a}$ & $\mathrm{n} / \mathrm{a}$ & $\mathrm{n} / \mathrm{a}$ \\
\hline Cost of sewage and waste disposal per & $£^{\prime} 000$ & $\mathrm{n} / \mathrm{a}$ & $\mathrm{n} / \mathrm{a}$ & $\mathrm{n} / \mathrm{a}$ & $\mathrm{n} / \mathrm{a}$ \\
\hline
\end{tabular}
enterprise

Food processing

Units

Food \& drink

Total UK manufacturing industry

Economic indicators

Number of enterprises

Total output

Total output

Output per enterprise

Output per enterprise

GVA

Labour productivity (GVA per workforce)

Large enterprises, turnover $£ 5 \mathrm{~m}+$

Imported products vs. domestic

Social indicators

Total employment, average per year

Employee per enterprise

Average gross wages per employee

Male vs. female employment full time labour

Environmental indicators

Purchase of energy for own consumption per enterprise

Purchase of water for own consumption per enterprise

Cost of sewage and waste disposal per enterprise

$£ ’ 000$
$‘ 000$ tonnes
$£ ’ 000$
‘000 tonnes
$£ ’ 000$
$£$
$\%$
$\%$

107

$2,063,000$

1,314

19,280

12.28

467,000

23,350

$37 \%$

$9 \%$

people

people
$£$ per yea

Eper year
$\%$

$$
\begin{aligned}
& 20,000 \\
& 186.92 \\
& 16,800
\end{aligned}
$$

$73 \%$

$£ ’ 000$

794

121

257

$£ ’ 000$

Units

Poultry

Potatoes

Agri-food

wholesale

Total UK

wholesale

Economic indicators

Number of enterprises

Total output

$£ ’ 000$

586

$1,345,500$

2,296
880

$2,245,700$

2,552
17,218

$70,032,000$

4,067
113,812

$388,989,000$ 3,412 
Table 2. Continued ${ }^{1}$.

Stage of the food supply chain/

Dimension of sustainability/Indicators

\begin{tabular}{|c|c|c|c|c|c|}
\hline Food wholesaling & Units & Poultry & Potatoes & $\begin{array}{l}\text { Agri-food } \\
\text { wholesale }\end{array}$ & $\begin{array}{l}\text { Total UK } \\
\text { wholesale }\end{array}$ \\
\hline GVA & $£^{\prime} 000$ & 165,300 & 349,400 & $7,678,000$ & $52,643,000$ \\
\hline Labour productivity (GVA per workforce) & $£$ & 24,309 & 47,216 & 34,124 & 42,834 \\
\hline Large enterprises, turnover $£ 5 \mathrm{~m}+$ & $\%$ & $9 \%$ & $13 \%$ & $7 \%$ & $7 \%$ \\
\hline Imported products vs. domestic & $\%$ & $22 \%$ & $21 \%$ & $38 \%$ & $\mathrm{n} / \mathrm{a}$ \\
\hline \multicolumn{6}{|l|}{ Social indicators } \\
\hline Total employment, average per year & people & 6,800 & 7,400 & 225,000 & $1,229,000$ \\
\hline Employee per enterprise & people & 11.6 & 8.4 & 13.1 & 10.8 \\
\hline Average gross wages per employee & £per year & 16,452 & 13,888 & 16,876 & 19,129 \\
\hline $\begin{array}{l}\text { Male vs. female employment full time } \\
\text { labour }\end{array}$ & $\%$ & $83 \%$ & $71 \%$ & $73 \%$ & $73 \%$ \\
\hline \multicolumn{6}{|l|}{ Environmental indicators } \\
\hline $\begin{array}{l}\text { Purchase of energy for own consumption } \\
\text { per enterprise }\end{array}$ & $£ ’ 000$ & 161 & 75 & 21 & 161 \\
\hline $\begin{array}{l}\text { Purchase of water for own consumption per } \\
\text { enterprise }\end{array}$ & $£^{\prime} 000$ & 13 & 5 & 1 & 8 \\
\hline $\begin{array}{l}\text { Cost of sewage and waste disposal per } \\
\text { enterprise }\end{array}$ & $£^{\prime} 000$ & 40 & 18 & 3 & 16 \\
\hline
\end{tabular}
enterprise

Food retailing

Units

Chicken

Food and

Total UK

Economic indicators

Number of enterprises

Total output

Total output

Output per enterprise

Output per enterprise

GVA

Labour productivity (GVA per workforce)

Large enterprises, turnover $£ 5 \mathrm{~m}+$

Imported products vs. domestic

Social indicators

Total employment, average per year

Employee per enterprise

Average gross wages per employee

Male vs. female employment full time labour

Environmental indicators

$£ ’ 000$
‘000 tonnes
$£ ’ 000$
'000 tonnes
$£ ’ 000$
$£$
$\%$
$\%$

1,800
$2,742,000$
$1,414^{8}$
1,523
0.79
144,500
17,000
$0.3 \%$
$22 \%$

\section{1,400}

$3,415,000$

3,338

2,439

2.38

86,800

12,765

$0.2 \%$

$21 \%$

$\begin{array}{ccc}\text { people } & 8,500 & 6,800 \\ \text { people } & 4.7 & 4.9 \\ \text { £per year } & 6,538 & 4,840 \\ \% & 75 \% & 54 \%\end{array}$

drink retail

retail

Purchase of energy for own consumption per enterprise

Purchase of water for own consumption per enterprise

Cost of sewage and waste disposal per enterprise

Food catering (non-residential)

$£^{\prime} 000$

$£^{\prime} 000$

$£ ’ 000$

Units

Economic indicators

Number of enterprises

Total output

Total output

Output per enterprise

Output per enterprise

GVA

\begin{tabular}{ccccc} 
& 2,062 & 8,500 & 107,739 & $1,619,195$ \\
$£ ’ 000$ & 488,000 & 700,000 & $46,436,000$ & $1,948,458,000$ \\
‘000 tonnes & 255 & 3,141 & n/a & n/a \\
$£ ' 000$ & 236 & 82 & 431 & 1,203 \\
‘000 tonnes & 0.12 & 0.36 & n/a & n $/ \mathrm{a}$ \\
$£ ’ 000$ & 234,000 & 324,000 & $18,002,000$ & $926,275,000$ \\
\hline
\end{tabular}

(continued) 
Table 2. Continued ${ }^{1}$.

Stage of the food supply chain/

Dimension of sustainability/Indicators

\begin{tabular}{|c|c|c|c|c|c|}
\hline Food catering (non-residential) & Units & Chicken & Potatoes & $\begin{array}{l}\text { Non-residential } \\
\text { catering }\end{array}$ & $\begin{array}{l}\text { Total UK } \\
\text { economy }\end{array}$ \\
\hline Labour productivity (GVA per workforce) & $£$ & 12,251 & 12,226 & 12,221 & 32,200 \\
\hline Large enterprises, turnover $£ 5 \mathrm{~m}+$ & $\%$ & $1 \%$ & $1 \%$ & $1 \%$ & $2 \%$ \\
\hline Imported products vs. domestic & $\%$ & $22 \%$ & $21 \%$ & $38 \%$ & $\mathrm{n} / \mathrm{a}$ \\
\hline \multicolumn{6}{|l|}{ Social indicators } \\
\hline Total employment, average per year & people & 19,100 & 26,500 & $1,473,000$ & $26,000,000$ \\
\hline Employee per enterprise & people & 9.3 & 3.1 & 13.7 & 16.1 \\
\hline Average gross wages per employee & $£$ £er year & 6,327 & 6,327 & 6,327 & 21,685 \\
\hline $\begin{array}{l}\text { Male vs. female employment full time } \\
\text { labour }\end{array}$ & $\%$ & $49 \%$ & $49 \%$ & $49 \%$ & $63 \%$ \\
\hline \multicolumn{6}{|l|}{ Environmental indicators } \\
\hline $\begin{array}{l}\text { Purchase of energy for own consumption } \\
\text { per enterprise }\end{array}$ & $£ ’ 000$ & 124 & 124 & 124 & $\mathrm{n} / \mathrm{a}$ \\
\hline $\begin{array}{l}\text { Purchase of water for own consumption per } \\
\text { enterprise }\end{array}$ & $£^{\prime} 000$ & 22 & 22 & 22 & $\mathrm{n} / \mathrm{a}$ \\
\hline $\begin{array}{l}\text { Cost of sewage and waste disposal per } \\
\text { enterprise }\end{array}$ & $£^{\prime} 000$ & 15 & 15 & 15 & $\mathrm{n} / \mathrm{a}$ \\
\hline Total food supply chain & Units & Chicken & Potatoes & $\begin{array}{l}\text { Food and } \\
\text { drink }\end{array}$ & $\begin{array}{l}\text { Total UK } \\
\text { economy }\end{array}$ \\
\hline \multicolumn{6}{|l|}{ Economic } \\
\hline Number of enterprises & & 5,280 & 15,421 & 342,035 & $1,619,195$ \\
\hline Total output & $£ ’ 000$ & $7,459,500$ & $8,304,700$ & $270,552,000$ & $1,948,458,000$ \\
\hline Total output & '000 tonnes & 1,698 & 6,479 & $\mathrm{n} / \mathrm{a}$ & $\mathrm{n} / \mathrm{a}$ \\
\hline GVA & $£ ’ 000$ & $1,010,800$ & $1,345,200$ & $69,950,000$ & $926,275,000$ \\
\hline Labour productivity (GVA per workforce) & $£$ & 15,887 & 26,019 & 17,474 & 32,200 \\
\hline Large enterprises & $\%$ & $12 \%$ & $11 \%$ & $7 \%$ & $2 \%$ \\
\hline Imported products vs. domestic & $\%$ & $17 \%$ & $16 \%$ & $30 \%$ & $\mathrm{n} / \mathrm{a}$ \\
\hline \multicolumn{6}{|l|}{ Social } \\
\hline Total employment, average per year & people & 63,624 & 51,700 & $4,003,000$ & $26,000,000$ \\
\hline Average gross wages per employee & £per year & 9,223 & 8,866 & 9,842 & 21,685 \\
\hline $\begin{array}{l}\text { Male vs. female employment full time } \\
\text { labour }\end{array}$ & $\%$ & $70 \%$ & $59 \%$ & $61 \%$ & $63 \%$ \\
\hline \multicolumn{6}{|l|}{ Environmental } \\
\hline $\begin{array}{l}\text { Purchase of energy for own consumption } \\
\text { per enterprise }\end{array}$ & $£^{\prime} 000$ & 274 & 437 & 314 & $\mathrm{n} / \mathrm{a}$ \\
\hline $\begin{array}{l}\text { Purchase of water for own consumption per } \\
\text { enterprise }\end{array}$ & $£^{\prime} 000$ & 39 & 59 & 30 & $\mathrm{n} / \mathrm{a}$ \\
\hline $\begin{array}{l}\text { Cost of sewage and waste disposal per } \\
\text { enterprise }\end{array}$ & $£^{\prime} 000$ & 79 & 83 & 45 & $\mathrm{n} / \mathrm{a}$ \\
\hline
\end{tabular}

Source: Adapted from Yakovleva (2007).

Notes: ${ }^{1}$ This work contains statistical data from ONS which is Crown copyright and reproduced with the permission of the controller of HMSO and Queen's Printer for Scotland. The use of the ONS statistical data in this work does not imply the endorsement of the ONS in relation to the interpretation or analysis of the statistical data.

${ }^{2}$ Holdings with more than 100,000 and over broilers are classified as large.

${ }^{3}$ Potato holdings with 20 ha of land and over.

${ }^{4}$ Agricultural holdings with 100 ha of land and over (data from Agriculture in the UK 2002).

${ }^{5}$ Enterprises with a turnover of more than $£ 5 \mathrm{~m}$.

${ }^{6}$ Average wages per person per year, full-time labour.

${ }^{7}$ Average wages per person per year, gross wages in agriculture divided by total employment in agriculture in 2002.

${ }^{8}$ The calculation of physical outputs in food retailing and non-residential catering is based on proportions that $15 \%$ of chickens are sold via food service and $85 \%$ via retail (Baxter 2003). 
Table 3. Scoring sustainability indicators.

\begin{tabular}{|c|c|c|c|c|c|c|c|}
\hline Indicators & 0 & 1 & 2 & 3 & 4 & 5 & 6 \\
\hline Mark & $\mathrm{n} / \mathrm{a}$ & Very poor & Poor & Fair & Average & Good & Excellent \\
\hline $\begin{array}{l}\text { Productivity (GVA per workforce, thousand } \\
\text { pounds) }\end{array}$ & $\mathrm{n} / \mathrm{a}$ & 0 & 12.0 & 24.0 & 36.0 & 48.0 & 60 \\
\hline Market concentration ( $\%$ of large enterprises) & $\mathrm{n} / \mathrm{a}$ & 40 & 32.0 & 24.0 & 16.0 & 8.0 & 0 \\
\hline Trade importance (import dependency, \%) & $\mathrm{n} / \mathrm{a}$ & 100 & 80.0 & 60.0 & 40.0 & 20.0 & 0 \\
\hline $\begin{array}{l}\text { Employment (employees per enterprise, } \\
\text { number of people) }\end{array}$ & $\mathrm{n} / \mathrm{a}$ & 0 & 4.0 & 8.0 & 12.0 & 16.0 & 20 \\
\hline $\begin{array}{l}\text { Wages (average gross wages per employee per } \\
\text { annum, thousand pounds) }\end{array}$ & $\mathrm{n} / \mathrm{a}$ & 0 & 5.4 & 10.8 & 16.2 & 21.6 & 27 \\
\hline $\begin{array}{l}\text { Gender balance (male vs. female employment } \\
\text { full time labour, \%) }\end{array}$ & $\mathrm{n} / \mathrm{a}$ & 100 & 90.0 & 80.0 & 70.0 & 60.0 & 50 \\
\hline $\begin{array}{l}\text { Energy use (purchase of energy for own } \\
\text { consumption per enterprise, thousand } \\
\text { pounds) }\end{array}$ & $\mathrm{n} / \mathrm{a}$ & 1000 & 800.0 & 600.0 & 400.0 & 200.0 & 0 \\
\hline $\begin{array}{l}\text { Water use (purchase of water for own con- } \\
\text { sumption per enterprise, thousand pounds) }\end{array}$ & $\mathrm{n} / \mathrm{a}$ & 80 & 64.0 & 48.0 & 32.0 & 16.0 & 0 \\
\hline $\begin{array}{l}\text { Waste (cost of sewage and waste disposal per } \\
\text { enterprise, thousand pounds) }\end{array}$ & $\mathrm{n} / \mathrm{a}$ & 100 & 80.0 & 60.0 & 40.0 & 20.0 & 0 \\
\hline
\end{tabular}

Note: 0-information not available, 1-lowest score, 6-highest score.

Source: Adapted from Yakovleva (2007).

sustainability benefit (the ranges could be adjusted depending on what level of granularity is sought for comparison purposes; six levels and a non-reporting/value level were seen as appropriate for discrimination in performance). The scale for each indicator was developed based on general notions of maximum and minimum desirable sustainability benefit or value and unacceptable or undesirable sustainability values. Then there was a linear interpolation on the six levels based on maximum and minimum scores. This approach is one example of linear normalisation, additional assumptions or characterisations (e.g. non-linearity along scales or expert evaluation of minimum and maximum scores) could be used. The indicator scores are defined in Table 3 . It must be noted that three indicators were chosen for each dimension of sustainability (economic, social and environmental) in the final scoring system (see Yakovleva 2007). The actual scores for each supply chain stage and food type are reported in Table 4.

\subsection{Adjusting the benchmarked scores using AHP}

This is the most intricate stage of the proposed methodological framework and will be demonstrated in detail using the case of food supply chains.

The values in Table 4 represent an adjusted score based on ranges as defined in Table 3. But, this rough estimate may not be adequate since it does not take into consideration the relative importance of each of these factors with respect to each other. To further this methodology we introduce a weighting scheme based on expert opinion to more accurately represent the performance of these actual supply chains. We complete this portion of the methodology by introducing a multi-attribute rating scheme, AHP.

AHP allows for a set of complex issues, factors and relationships, which have an impact on an overall objective, to be compared with the importance of each issue relative to its impact on the solution of the problem (Saaty 1980). Other approaches that can define the factor utilities and how well each of the alternatives may rank on the various factors may also be used. For example, the Analytic Network Process (ANP) is a more general form of AHP which could also

195 be used in this context. In brief, ANP does not require the same strict hierarchical structure between elements as AHP and can accommodate feedback and interdependencies among various elements. However, ANP typically requires much greater effort for comparison of additional linkages. It may also be disadvantageous to decision makers who wish to understand the technique, the complexities of ANP may not allow for this ease of understanding and transparency. For example, a simple decision model presented by Saaty (1996) with three alternatives compared with respect to four criteria requires a minimum of 12 pairwise comparisons for AHP, but over 600 
Table 4. Indicator cores for each stage of supply chain and food type.

\begin{tabular}{|c|c|c|c|c|c|c|c|c|c|}
\hline \multirow[b]{3}{*}{ Supply Chain Stage/Food Type } & \multicolumn{9}{|c|}{ Indicators } \\
\hline & \multicolumn{3}{|c|}{ Economic } & \multicolumn{3}{|c|}{ Social } & \multicolumn{3}{|c|}{ Environmental } \\
\hline & A & $\mathrm{B}$ & $\mathrm{C}$ & $\mathrm{D}$ & $\mathrm{E}$ & $\mathrm{F}$ & G & $\mathrm{H}$ & I \\
\hline \multicolumn{10}{|l|}{ Agriculture } \\
\hline Chicken & 0.00 & 4.50 & 6.00 & 4.18 & 0.00 & 0.00 & 0.00 & 0.00 & 0.00 \\
\hline Potato & 0.00 & 4.00 & 5.55 & 0.00 & 0.00 & 0.00 & 0.00 & 0.00 & 0.00 \\
\hline Benchmark: Food & 2.08 & 4.25 & 4.10 & 1.95 & 1.64 & 0.00 & 0.00 & 0.00 & 0.00 \\
\hline \multicolumn{10}{|l|}{ Food processing } \\
\hline Chicken & 2.95 & 1.38 & 4.90 & 6.00 & 4.11 & 3.70 & 2.03 & 1.00 & 1.00 \\
\hline Potato & 5.43 & 2.63 & 5.65 & 6.00 & 4.57 & 4.80 & 1.00 & 1.00 & 1.00 \\
\hline Benchmark: Food and drink & 4.35 & 4.13 & 5.25 & 6.00 & 4.37 & 4.00 & 2.83 & 1.81 & 1.00 \\
\hline \multicolumn{10}{|l|}{ Food wholesale } \\
\hline Chicken & 3.03 & 4.88 & 4.90 & 3.90 & 4.05 & 2.70 & 5.20 & 5.19 & 4.00 \\
\hline Potato & 4.93 & 4.38 & 4.95 & 3.10 & 3.57 & 3.90 & 5.63 & 5.69 & 5.10 \\
\hline Benchmark: Agro-food wholesale & 3.84 & 5.13 & 4.10 & 4.28 & 4.13 & 3.70 & 5.90 & 5.94 & 5.85 \\
\hline \multicolumn{10}{|l|}{ Food retail } \\
\hline Chicken & 2.42 & 5.96 & 4.90 & 2.18 & 2.21 & 3.50 & 5.93 & 5.94 & 5.85 \\
\hline Potato & 2.06 & 5.98 & 4.95 & 2.23 & 1.90 & 5.60 & 5.94 & 5.94 & 5.90 \\
\hline Benchmark: Food and drink & 2.15 & 5.88 & 4.10 & 5.73 & 2.45 & 5.60 & 3.62 & 4.00 & 4.00 \\
\hline \multicolumn{10}{|l|}{ Food catering } \\
\hline Chicken & 2.02 & 5.88 & 4.90 & 3.32 & 2.17 & 6.00 & 5.38 & 4.63 & 5.25 \\
\hline Potato & 2.02 & 5.88 & 4.95 & 1.78 & 2.17 & 6.00 & 5.38 & 4.63 & 5.25 \\
\hline Benchmark: Non-residential catering & 2.02 & 5.88 & 4.10 & 4.42 & 2.17 & 6.00 & 5.38 & 4.63 & 5.25 \\
\hline
\end{tabular}

Notes: $\mathrm{A}=$ Labour productivity (GVA per workforce). $\mathrm{B}=$ Large enterprises, turnover $£ 5 \mathrm{~m}+$. C $=$ Imported products vs. domestic. $\mathrm{D}=$ Employees per enterprise. $\mathrm{E}=$ Average gross wages per employee. $\mathrm{F}=$ Male vs. female employment full time labour. $\mathrm{G}=$ Purchase of energy for own consumption per enterprise. $\mathrm{H}=$ Purchase of water for own consumption per enterprise. $\mathrm{I}=$ Cost of sewage and waste disposal per enterprise

comparisons for an ANP model that accounts for all possible dependencies. Thus, we chose AHP for this application because it is easy to understand and implement. Future research will benefit from possible application of ANP.

AHP utilises a decision-making framework that assumes a unidirectional hierarchical relationship among decision levels. Thus, the first major step in the AHP process is to define the decision hierarchy, which would include overall objective, factors, subfactors (if necessary) and alternatives.

The second major step in the AHP process is to elicit the preferences through pairwise comparisons of the various factors. This step is completed by asking a series of questions that compare the relative importance or influence of one factor (technique) when compared to another factor (technique) on a 'controlling' factor. Saaty (1980) suggests that the comparisons of the factors be made in the range 1/9 to 9. A 9 indicates that one factor is 210 extremely more important than the other, a 1/9 indicates that one factor is extremely less important than the other, and a $l$ indicates equal importance. These pairwise comparisons are summarised in a matrix, and one matrix is used for each controlling variable. One pairwise comparison matrix will be formed for the comparisons of the categories on each of the factors.

The third step in the AHP process is to complete the evaluations of the factors and alternatives relative importance weights by determining a local priority vector is computed as the unique solution to:

$$
A w=\lambda_{\max } w,
$$

where $\lambda_{\max }$ is the largest eigenvalue of $A$, the pairwise comparison matrix of the factors under consideration. Saaty (1980) provides several algorithms for approximating $w$, the final relative importance weights of the factors. We used Web HIPRE3+ (Mustajoki and Hämäläinen 1999), an Internet, interactive software decision support tool available for decision analysis (http://www.hipre.hut.fi/), to compute the eigenvalues and relative importance weights for our study.

The final stage in the overall benchmarking methodology is the sensitivity analysis which will be described fully at the end of the case example. 


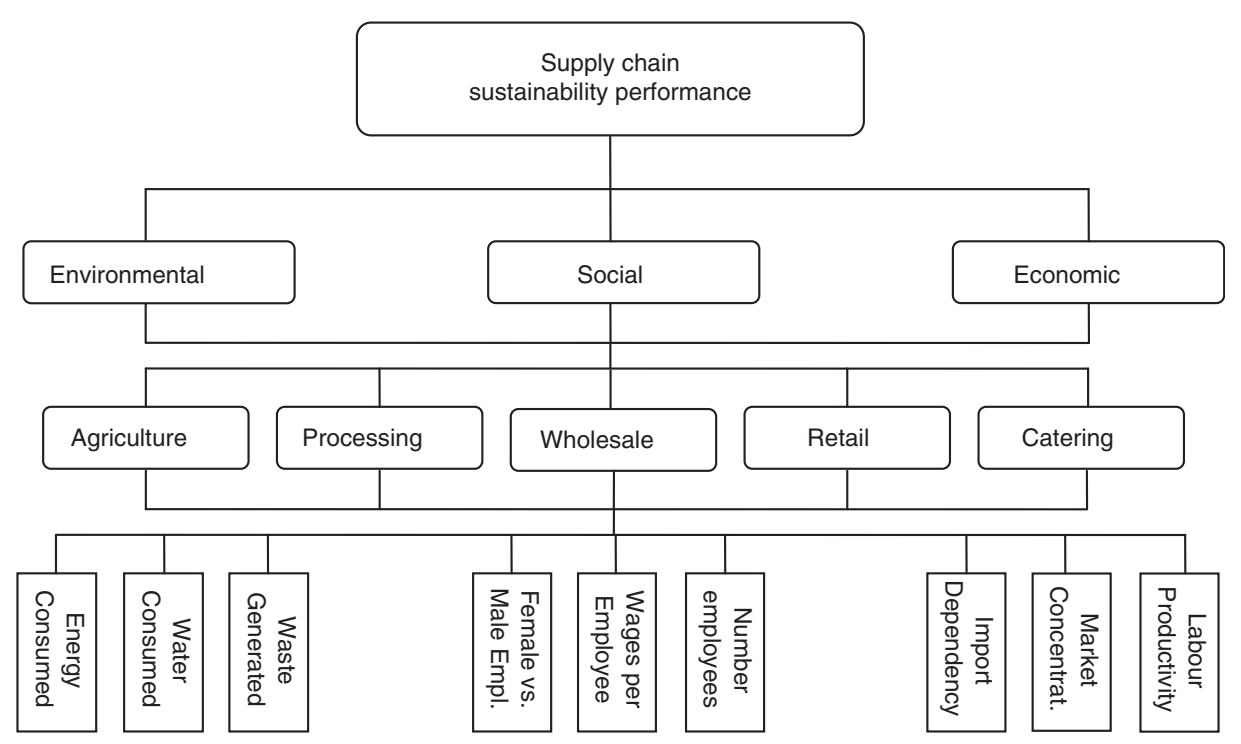

Figure 1. Supply chain sustainability hierarchy.

\section{Case study: applying the methodology to food supply chains}

We now apply the AHP process described above to the chicken and potato supply chains in the UK. The first step is to define the hierarchy, illustrated for this study in Figure 1. The top level of our hierarchy consists of these three corresponding dimensions: environmental, social and economic dimensions. These are only exemplary dimensions, other dimensions may be used to define sustainability; however, these three are generally accepted as the primary factors. The hierarchy is further decomposed into various sub-elements. The food supply chain itself, represented by five distinct stages, is the next level. The stages include agriculture, processing, wholesale, retail, and catering. Again, one could argue that there should be more stages or fewer stages. We feel that a five-stage model captures the essence of the supply chain, including an appropriate level of detail. The third and final level of the hierarchy is made up of the specific measures used to evaluate the sustainability of the supply chain stages. These measures are the indicators summarised in Table 3, which include labour productivity, number of employees, cost of waste disposal and so on.

\subsection{Expert opinion}

For the current study, we surveyed a small group of food supply chain experts to determine relative importance weights of chosen indicators in the supply chain. Experts who specialise in chicken and potato production and distribution and have an in-depth knowledge of food supply chain operations at the national level with significant work experience at a specific link the supply chain (agricultural production, food manufacturing, food wholesale, food retail and industry association) have been approached to participate in the study. All the experts were previously interviewed on the subject of sustainability in the food supply chain and were determined to be key managers in operations of highly concentrated chicken and potato supply chains in the UK. Out of the 18 experts approached for the study, five responded by filling in the questionnaire; for this study we selected four fully completed questionnaire responses from the actual respondents. Experts whose responses were used for the AHP development include: (1) a potato expert who is a senior manager at a national industry association with marketing expertise and 30 years work experience in food retailing; (2) a chicken expert who is a senior manager within a national industry association with expertise in food safety and food technology and 13 years work experience in the food industry; (3) retail expert 1 is a senior manager at a large supermarket chain with expertise in product development and quality assurance and 15 years work experience in food retail; and (4) retail expert 2 is a senior manager at a large supermarket chain with expertise on technical development with 17 years work experience in the food industry. 
Table 5. Pairwise comparisons and ratings of sustainability dimensions by potato expert.

\begin{tabular}{lcccc}
\hline Dimension & Environmental & Social & Economic & $\begin{array}{c}\text { Importance } \\
\text { Rating }\end{array}$ \\
\hline Environmental & 1 & 1 & $1 / 5$ & 0.177 \\
Social & 1 & 1 & 1 & 0.304 \\
Economic & 5 & 1 & 1 & 0.519 \\
\hline
\end{tabular}

Table 6. Pairwise comparisons and ratings of sustainability dimensions by chicken expert.

\begin{tabular}{lcccc}
\hline Dimension & Environmental & Social & Economic & $\begin{array}{c}\text { Importance } \\
\text { Rating }\end{array}$ \\
\hline Environmental & 1 & $1 / 7$ & $1 / 3$ & 0.085 \\
Social & 7 & 1 & $1 / 9$ & 0.215 \\
Economic & 3 & 9 & 1 & 0.700 \\
\hline
\end{tabular}

As part of this weight elicitation process, a questionnaire was developed. The initial portions of the questionnaire provided some definitions of the factors to be evaluated. These definitions are important to help respondents be more consistent in their evaluations. An excerpt from the full questionnaire is shown in Appendix A. All of the questions in the questionnaire are formulated as pairwise comparisons and are used to construct the pairwise comparison matrices. For this hierarchy we needed responses to 88 pairwise comparison questions. Respondents were asked to make a series of pairwise comparisons for each level of the hierarchy discussed above. For example, with respect to the top level, the following three questions were posed:

- How significant are environmental factors when compared to economic factors?

- How significant are environmental factors when compared to social factors?

- How significant are social factors when compared to economic factors?

The responses were represented on a 1-9 Likert-type scale with a ' 1 ' response representing the $1 / 9$ value, meaning extremely less important, and a ' 9 ' response meaning extremely more important. Table 5 reports the importance ratings derived from the responses of a potato supply chain expert. The numbers listed in boxes reflect the responses to the three groupings of questions above. The diagonal elements of the matrix are 1s, by definition, since they represent the comparison of an item with itself. Once the importance of one factor with respect to a second is given, then the importance of the second factor with respect to the first is the reciprocal. This process is how the remaining elements of the matrix are derived. In this way, the three questions completely characterise the nine pairwise comparisons of the environmental, social, and economic factors. Using these numbers as inputs, AHP determines the relative importance scores of each of the factors. These importance rating scores, reported in the last column of Table 5, represent the relative weight that this expert places on each top-level dimension (note that the values sum to 1). These results show that this expert felt the environmental issues were of less significance than both social and economic issues in the potato supply chain.

Similarly, Table 6 reports the results of the pairwise comparisons based on the responses of a chicken supply chain expert. As expected, different responses to the survey questions yield different importance ratings. It is interesting to note, however, that although the ratings are different, the rank orderings correlate perfectly, i.e. environmental has the lowest weight and economic has the highest weight for both experts.

This process of eliciting responses is repeated for each level of the hierarchy, comparing each stage of the supply chain with respect to each dimension of sustainability and then comparing each indicator (such as labour productivity) with respect to each stage of the supply chain. A similar process was used to obtain ratings from the retail experts for each level of the hierarchy (to conserve space, the ratings are not reported here).

\subsection{Computing the overall sustainability index}

Once the responses to all of the questions have been elicited, AHP is used to compute the relative adjustment ratings. The final output is a set of importance ratings for each expert for all of the indicators at the bottom of the hierarchy

285 illustrated in Figure 1. The final AHP output for one potato expert is displayed in Table 7. The relative importance weighting from Table 6 for the potato expert's environmental sustainability dimension (0.177), appear as 'local' importance ratings, the second column, for the environmental factor in Table 7 . The relative importance rating for the impact of each of the supply chain stages is shown in the fourth column of Table 7. For example, the agricultural stage of the potato supply chain has the highest (local) relative importance rating (0.535) in its influence on the environmental sustainability dimension. The (local) relative importance of each of the sustainability indicators for a given sustainability dimension and supply chain stage appears in the sixth column of Table 7 . The environmental 
Table 7. AHP final output - global importance ratings for potato expert.

\begin{tabular}{|c|c|c|c|c|c|c|}
\hline $\begin{array}{l}\text { Sustainability } \\
\text { Dimension }\end{array}$ & $\begin{array}{l}\text { Importance } \\
\text { Rating }\end{array}$ & $\begin{array}{c}\text { Supply } \\
\text { Chain Stage }\end{array}$ & $\begin{array}{l}\text { Importance } \\
\text { Rating }\end{array}$ & $\begin{array}{l}\text { Sustainability } \\
\text { Indicator }\end{array}$ & $\begin{array}{l}\text { Importance } \\
\text { Rating }\end{array}$ & $\begin{array}{c}\text { Global } \\
\text { Importance Rating }\end{array}$ \\
\hline Environmental & 0.177 & Agriculture & 0.535 & Energy consumed & 0.567 & 0.05369 \\
\hline Environmental & 0.177 & Agriculture & 0.535 & Water consumed & 0.323 & 0.03059 \\
\hline Environmental & 0.177 & Agriculture & 0.535 & Waste generated & 0.110 & 0.01042 \\
\hline Environmental & 0.177 & Food Processing & 0.264 & Energy consumed & 0.319 & 0.01491 \\
\hline Environmental & 0.177 & Food Processing & 0.264 & Water consumed & 0.460 & 0.02149 \\
\hline Environmental & 0.177 & Food Processing & 0.264 & Waste generated & 0.221 & 0.01033 \\
\hline Environmental & 0.177 & Food Wholesale & 0.035 & Energy consumed & 0.778 & 0.00482 \\
\hline Environmental & 0.177 & Food Wholesale & 0.035 & Water consumed & 0.111 & 0.00069 \\
\hline Environmental & 0.177 & Food Wholesale & 0.035 & Waste generated & 0.111 & 0.00069 \\
\hline Environmental & 0.177 & Food Retail & 0.134 & Energy consumed & 0.333 & 0.00790 \\
\hline Environmental & 0.177 & Food Retail & 0.134 & Water consumed & 0.333 & 0.00790 \\
\hline Environmental & 0.177 & Food Retail & 0.134 & Waste generated & 0.333 & 0.00790 \\
\hline Environmental & 0.177 & Food Catering & 0.032 & Energy consumed & 0.333 & 0.00189 \\
\hline Environmental & 0.177 & Food Catering & 0.032 & Water consumed & 0.333 & 0.00189 \\
\hline Environmental & 0.177 & Food Catering & 0.032 & Waste generated & 0.333 & 0.00189 \\
\hline Social & 0.304 & Agriculture & 0.233 & Employment & 0.715 & 0.05064 \\
\hline Social & 0.304 & Agriculture & 0.233 & Wages/employee & 0.218 & 0.01544 \\
\hline Social & 0.304 & Agriculture & 0.233 & Gender Ratio & 0.067 & 0.00475 \\
\hline Social & 0.304 & Food Processing & 0.342 & Employment & 0.460 & 0.04783 \\
\hline Social & 0.304 & Food Processing & 0.342 & Wages/employee & 0.221 & 0.02298 \\
\hline Social & 0.304 & Food Processing & 0.342 & Gender Ratio & 0.319 & 0.03317 \\
\hline Social & 0.304 & Food Wholesale & 0.041 & Employment & 0.742 & 0.00925 \\
\hline Social & 0.304 & Food Wholesale & 0.041 & Wages/employee & 0.203 & 0.00253 \\
\hline Social & 0.304 & Food Wholesale & 0.041 & Gender Ratio & 0.055 & 0.00069 \\
\hline Social & 0.304 & Food Retail & 0.218 & Employment & 0.633 & 0.04195 \\
\hline Social & 0.304 & Food Retail & 0.218 & Wages/employee & 0.304 & 0.02015 \\
\hline Social & 0.304 & Food Retail & 0.218 & Gender Ratio & 0.063 & 0.00418 \\
\hline Social & 0.304 & Food Catering & 0.166 & Employment & 0.701 & 0.03538 \\
\hline Social & 0.304 & Food Catering & 0.166 & Wages/employee & 0.204 & 0.01029 \\
\hline Social & 0.304 & Food Catering & 0.166 & Gender Ratio & 0.095 & 0.00479 \\
\hline Economic & 0.519 & Agriculture & 0.078 & Labour productivity & 0.701 & 0.02838 \\
\hline Economic & 0.519 & Agriculture & 0.078 & Market Concentration & 0.202 & 0.00818 \\
\hline Economic & 0.519 & Agriculture & 0.078 & Import Dependency & 0.097 & 0.00393 \\
\hline Economic & 0.519 & Food Processing & 0.302 & Labour productivity & 0.429 & 0.06724 \\
\hline Economic & 0.519 & Food Processing & 0.302 & Market Concentration & 0.143 & 0.02241 \\
\hline Economic & 0.519 & Food Processing & 0.302 & Import Dependency & 0.429 & 0.06724 \\
\hline Economic & 0.519 & Food Wholesale & 0.033 & Labour productivity & 0.685 & 0.01173 \\
\hline Economic & 0.519 & Food Wholesale & 0.033 & Market Concentration & 0.234 & 0.00401 \\
\hline Economic & 0.519 & Food Wholesale & 0.033 & Import Dependency & 0.080 & 0.00137 \\
\hline Economic & 0.519 & Food Retail & 0.466 & Labour productivity & 0.685 & 0.16567 \\
\hline Economic & 0.519 & Food Retail & 0.466 & Market Concentration & 0.234 & 0.05659 \\
\hline Economic & 0.519 & Food Retail & 0.466 & Import Dependency & 0.080 & 0.01935 \\
\hline Economic & 0.519 & Food Catering & 0.121 & Labour productivity & 0.726 & 0.04559 \\
\hline Economic & 0.519 & Food Catering & 0.121 & Market Concentration & 0.198 & 0.01243 \\
\hline Economic & 0.519 & Food Catering & 0.121 & Import Dependency & 0.076 & 0.00477 \\
\hline
\end{tabular}

Note: Global importance ratings may not sum to 1 due to rounding error.

sustainability dimension at the agricultural stage has energy consumed as the most important of the three sustainability indicators with a local score of 0.567 (when compared with water consumed, 0.323 , and waste generated, 0.110). The global importance rating is determined by taking the product of each of the local scores for a given row. For example, for the energy consumed by the agriculture supply chain stage's environmental sustainability dimension, the global importance rating is the product of $(0.567) *(0.535) *(0.177)=0.05369$. The mathematical expression is simply:

$$
\mathrm{GIR}_{i j k}=\mathrm{SD}_{i} * \mathrm{SCS}_{j} * \mathrm{SI}_{k}
$$


Table 8. Overall sustainability index based on potato expert.

\begin{tabular}{|c|c|c|c|c|c|c|c|c|c|c|}
\hline & \multicolumn{3}{|c|}{ Economic } & \multicolumn{3}{|c|}{ Social } & \multicolumn{3}{|c|}{ Environmental } & \multirow[b]{2}{*}{ Total } \\
\hline & $\begin{array}{l}\text { Labour } \\
\text { Prod. } \\
\text { (A) }\end{array}$ & $\begin{array}{l}\text { Market } \\
\text { Concen. } \\
\text { (B) }\end{array}$ & $\begin{array}{l}\text { Import } \\
\text { Depend. } \\
\text { (C) }\end{array}$ & $\begin{array}{l}\text { Employ- } \\
\text { ment } \\
\text { (D) }\end{array}$ & $\begin{array}{l}\text { Wages/ } \\
\text { Emp. } \\
\text { (E) }\end{array}$ & $\begin{array}{c}\text { Gender } \\
\text { Ratio } \\
\text { (F) }\end{array}$ & $\begin{array}{l}\text { Energy } \\
\text { Usage } \\
(\mathrm{G})\end{array}$ & $\begin{array}{c}\text { Water } \\
\text { Usage } \\
(\mathrm{H})\end{array}$ & $\begin{array}{c}\text { Waste } \\
\text { Generated } \\
\text { (I) }\end{array}$ & \\
\hline Agriculture & 0.000 & 0.033 & 0.022 & 0.000 & 0.000 & 0.000 & 0.000 & 0.000 & 0.000 & 0.055 \\
\hline Food processing & 0.365 & 0.059 & 0.380 & 0.287 & 0.105 & 0.159 & 0.015 & 0.021 & 0.010 & 1.402 \\
\hline Food wholesale & 0.058 & 0.018 & 0.007 & 0.029 & 0.009 & 0.003 & 0.027 & 0.004 & 0.004 & 0.157 \\
\hline Food retail & 0.341 & 0.338 & 0.096 & 0.094 & 0.038 & 0.023 & 0.047 & 0.047 & 0.047 & 1.071 \\
\hline Food catering & 0.092 & 0.073 & 0.024 & 0.063 & 0.022 & 0.029 & 0.010 & 0.009 & 0.010 & 0.332 \\
\hline Total & 0.856 & 0.521 & 0.528 & 0.472 & 0.175 & 0.214 & 0.099 & 0.081 & 0.070 & 3.016 \\
\hline
\end{tabular}

Note: Sustainability index is the sum of indicator scores times global important ratings $=3.016$.

Table 9. Overall sustainability index based on chicken expert.

\begin{tabular}{|c|c|c|c|c|c|c|c|c|c|c|}
\hline & \multicolumn{3}{|c|}{ Economic } & \multicolumn{3}{|c|}{ Social } & \multicolumn{3}{|c|}{ Environmental } & \multirow[b]{2}{*}{ Total } \\
\hline & $\begin{array}{l}\text { Labour } \\
\text { Prod. } \\
\text { (A) }\end{array}$ & $\begin{array}{l}\text { Market } \\
\text { Concen. } \\
\text { (B) }\end{array}$ & $\begin{array}{l}\text { Import } \\
\text { Depend. } \\
\text { (C) }\end{array}$ & $\begin{array}{l}\text { Employ- } \\
\text { ment } \\
\text { (D) }\end{array}$ & $\begin{array}{c}\text { Wages/ } \\
\text { Emp. } \\
\text { (E) }\end{array}$ & $\begin{array}{c}\text { Gender } \\
\text { Ratio } \\
\text { (F) }\end{array}$ & $\begin{array}{c}\text { Energy } \\
\text { Usage } \\
\text { (G) }\end{array}$ & $\begin{array}{c}\text { Water } \\
\text { Usage } \\
(\mathrm{H})\end{array}$ & $\begin{array}{c}\text { Waste } \\
\text { Generated } \\
\text { (I) }\end{array}$ & \\
\hline Agriculture & 0.000 & 0.038 & 0.087 & 0.000 & 0.000 & 0.000 & 0.000 & 0.000 & 0.000 & 0.137 \\
\hline Food processing & 0.633 & 0.142 & 0.146 & 0.072 & 0.034 & 0.021 & 0.032 & 0.003 & 0.002 & 1.085 \\
\hline Food wholesale & 0.072 & 0.104 & 0.019 & 0.035 & 0.017 & 0.006 & 0.024 & 0.002 & 0.005 & 0.285 \\
\hline Food retail & 0.221 & 0.544 & 0.064 & 0.084 & 0.041 & 0.031 & 0.041 & 0.003 & 0.018 & 1.049 \\
\hline Food catering & 0.093 & 0.082 & 0.105 & 0.194 & 0.061 & 0.081 & 0.014 & 0.003 & 0.001 & 0.635 \\
\hline Total & 1.019 & 0.911 & 0.422 & 0.396 & 0.154 & 0.139 & 0.111 & 0.012 & 0.026 & 3.178 \\
\hline
\end{tabular}

Note: Sustainability index is the sum of indicator scores times global important ratings $=3.178$.

where $\mathrm{GIR}_{i j k}=$ global relative importance rating for Sustainability Indicator $k$ of Supply Chain Stage $j$, Sustainability Indicator $I, \mathrm{SD}_{i}=$ local relative importance rating for the Sustainability Dimension $I, \mathrm{SCS}_{j}=$ local relative importance rating for the Supply Chain Stage $j$ and $\mathbf{S I}_{k}=$ local relative importance rating for the Sustainability Indicator $k$.

An overall sustainability index is computed by weighting the indicator scores reported in Table 4 by the global ratings of Table 7. The index is simply the sum of the indicator scores multiplied by the global ratings. Table 8 shows the results for one potato expert. The overall sustainability of the potato supply chain, based on the data in Table 4

305 and the opinions in Table 7, is 3.016. Each element of the table equals the indicator score times the global importance rating. For example, the value for labour productivity (the first economic dimension) for the retail link in the potato supply chain is computed as $(0.166) *(2.06)=0.341$, where 0.166 is the global relative importance rating for the labour productivity indicator (Table 7) and 2.06 is the indicator score for the retail link of the potato supply chain (Table 4). Similar computations are performed for each sustainability indicator and supply chain link combination; these products are then summed to get the total index of 3.016.

This methodology is also applied to the chicken supply chain, using the data reported in Table 2 and the evaluations of a chicken supply chain expert (see Table 6 for the top-level ratings). Translating the opinions into numerical importance ratings and multiplying the indicator scores by these ratings yields an overall sustainability index of 3.178, as reported in Table 9. The overall score shows that based on the expert opinions of relative 315 importance and the baseline performance numbers we arrive at a higher overall rating for the chicken supply chain's sustainability index. Although data collected for calculation of indicators (especially at the stage of agriculture) are not complete, this result would mean that in comparison with the potato supply chain, the chicken supply chain is closer to achieving sustainability objectives within three dimensions: economic, social and environmental. 
An advantage of the scoring and the weighting scheme is that we can arrive at a single sustainability index score for the overall supply chain as well as scores for each individual stage, thus helping to inform decision making at the strategic, tactical and operational levels by organisations inside and outside of the supply chain. For example, the processing stage of both supply chains has the largest influence on sustainability when aggregated and weighted, as shown in Tables 8 and 9. From a strategic perspective, large food retailer could use these results as incentive to build partnerships with food processors, for example, with the aim of increasing overall supply chain sustainability. This retailer could also observe that the retail stage itself is a major factor in overall sustainability; therefore, its own tactics and operations play an important role. The ratings can help guide firms' decisions about the use of recycled and less energy intensive materials as well. From a tactical and operational perspective, an individual processing firm could use these results as an impetus to study and model operational practices of other processing firms. Policy makers seeking to understand and improve sustainability can examine what aspects of the processing stage make it more sustainable for the potato supply chain than the chicken supply chain, even though the chicken supply chain has a higher overall sustainability score. The analysis could also examine the various sustainability dimensions and their scoring.

Thus, the results can be used at different levels and by different actors inside and outside of the supply chain. In the absence of these benchmarks, a firm has little objective guidance to direct its efforts towards increasing sustainability. And, as will be demonstrated in the next section, sensitivity analyses can be performed to evaluate how robust the specific numbers are with respect to variations in different inputs, giving decision-makers confidence in the final results. ${ }^{1}$

Next, we examine the sustainability scores with respect to the retail experts' opinions. The retail experts do not have in-depth knowledge of specific supply chains and were not asked to evaluate the potato or chicken supply chains specifically; therefore, we use their opinions to complement the area experts. Specifically, we first computed global importance ratings for each retail expert for each supply chain using the same process described above. We then computed an average global importance rating for the potato supply chain using the potato expert and the two retail experts. The average was computed as a weighted geometric mean, as is usual when combining separate ratings of individual experts (Forman and Peniwati 1998). Since the potato supply chain expert has more detailed knowledge of this chain, we placed a weight of 0.5 on his/her ratings and placed a weight of 0.25 on the ratings of each of the retail experts (for a total weight of 1.0). Various other weighting schemes were examined - including equal weights for all experts - and each produced similar results. Combining the ratings in this way recognises the experts' area knowledge while reducing the possibility of extreme bias. The average global importance rating was then used to compute the overall sustainability index (as described above), yielding an average overall result of 2.859 for the potato supply chain. Using the same process for the chicken supply chain yields an average overall sustainability index of 3.004. To further understand the robustness of these results and to attain additional insights, we perform a sensitivity analysis.

\subsection{Sensitivity analysis}

The final stage of our overall benchmarking methodology is the sensitivity analysis stage. We seek to determine the overall robustness of the sustainability numbers to perturbations in the data. That is, if other experts were asked to rate the importance of different supply chain dimensions and indicators, how much would the final results change? The sensitivity analysis also shows the tradeoffs that are implicitly assumed by the various experts. Some tradeoffs have greater marginal implications for experts and supply chains. This type of trade-off analysis is critical to identify potential stakeholder responses to various valuations as well as implications to performance of stages and overall supply chain sustainability. Sensitivity analysis is also useful in providing insights due to the dynamics of sustainability perceptions and importance over time. To demonstrate some of these issues, we perform sensitivity analysis on the economic dimension of the top-level hierarchy for both the potato and chicken supply chains. We chose this dimension because the area expert for each supply chain gave it the highest weight, but the process discussed below could be used for any dimension or link. Based on the questionnaire responses from the potato supply chain expert, the economic dimension has a weight of 0.519 , the social dimension has a weight of 0.304 , and the environmental dimension has a weight of 0.177 . To understand how sensitive the overall sustainability index is to changes in the weight on the economic dimension, we vary this weight from 0 to 1 , while keeping the ratio of the other two dimensions the same. The ratio of social to environmental is currently $0.632(=0.304 /[0.304+0.177])$, and 


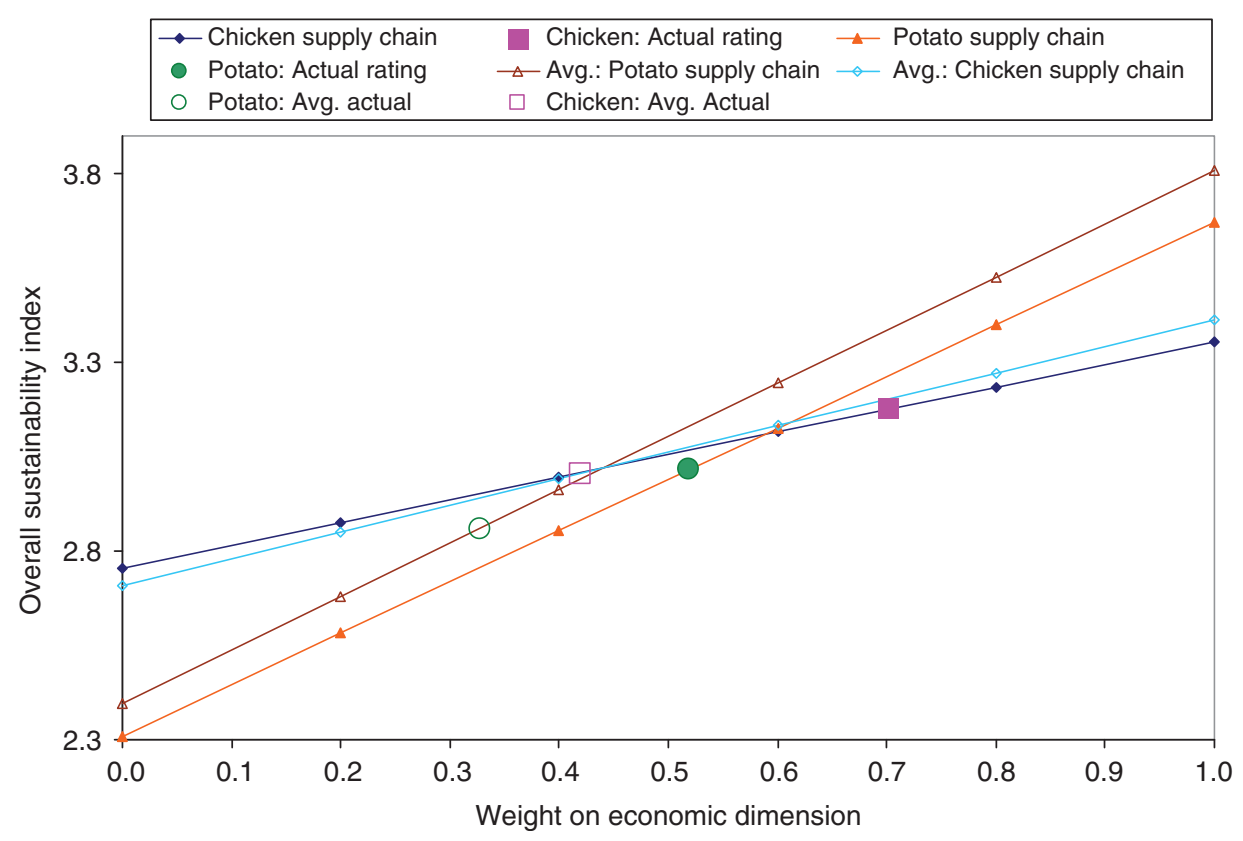

Figure 2. Changes in overall sustainability index as a function weight placed on economic dimension of hierarchy.

the ratio of environmental to social is currently $0.368(=0.177 /[0.304+0.177])$. Thus, if the economic dimension has a score of 0 , then the social dimension will have a score of 0.632 and the environmental dimension will have a score of 0.368 , maintaining the same ratios. If the economic dimension has a score of 0.2 , then social dimension will have a score of $0.506(=0.632 *[1-0.2])$ and the environmental dimension will have a score of $0.294(=0.368 *[1-0.2])$. Changing the top-level weights will also change the global importance ratings and yield a different overall sustainability index. Figure 2 illustrates how the overall sustainability index changes as the weight on the economic dimension changes. The same process was used to generate results for the chicken supply chain and for the average indices computed using the retail experts' opinions. All of the results are shown in Figure 2, along with the actual (original) scores.

In Figure 2 there are four sensitivity ranges (lines) and four original points identified. The four include: (1) The chicken supply chain sensitivity of the chicken expert only; (2) The average chicken supply chain sensitivity that is the weighted average for the chicken expert and the two retail experts; (3) The potato supply chain sensitivity of the potato expert only; and (4) The average potato supply chain sensitivity that is the weighted average for the potato expert and the two retail experts.

As the figure indicates, the sustainability index of potato supply chain is more sensitive than that of the chicken supply chain to changes in the weight on the economic dimension (this result is true for the basic potato supply chain and the averaged potato supply chain). Although the index for potato chain ranges from 2.3-3.7, the index for the chicken chain only ranges from approximately 2.8-3.3. Similarly, the averaged sustainability index for the potato supply chain ranges from approximately $2.4-3.8$, and the averaged sustainability index for the chicken supply chain ranges from approximately 2.7-3.4. The data in Table 4 suggest that the potato supply chain performs better than the chicken supply chain in terms of the economic indicators. It is likely that the improved performance in one area is coming at the expense (trading-off) of other areas. The potato chain is less sustainable overall, according to the experts and the proposed measures. In any case, this situation illustrates how focus on a single dimension may miss the mark in terms of evaluating the overall health and sustainability of the supply chain and the importance of the consideration of tradeoffs within and between factors. Another general observation is that each of the overall sustainability scores tends to increase for each supply chain based on the increasing importance of economic factors. Sensitivity analyses were carried out for both of the other two factors (to conserve space, the details have been omitted), and their overall sustainability scores decrease due to their lesser weighted importance than the economic factor. 


\section{Discussion and conclusion}

400 One effective way for managers and policy makers to improve the sustainability of supply chains is to complete a benchmarking exercise to determine how well specific supply chains perform. To complete such evaluation of sustainability performance we have introduced a methodology that can help benchmark supply chains based on sustainability factors. We introduced this technique using real world data and expert opinion for the food supply chain.

405 The results show that experts give considerably different relative weights to various elements of sustainability in the supply chain. Selected industry experts generally give higher weight to economic indicators as oppose to environmental and social indicators. Indeed, we acknowledge that all experts approached in this study belong to the industrial sector, whilst experts from civil society and public policy organisations may differ in their opinion on importance ratings of sustainability indicators. Potential users of the framework may wish to consult various stakeholder groups during the entire process of sustainability index creation: (1) during the selection of sustainability indicators to be included in the assessment as suggested by Courville (2003); (2) consult them on what would be those desirable sustainability performance targets before ranging the indicators from 1-6; and (3) determine importance ratings of indicators in the framework.

The calculated sustainability indices show that according to experts' opinion the chicken supply chain has a higher sustainability index than the potato supply chain. Although we have data shortages for the stage of agriculture, judging from the results we can state that the chicken supply chain is closer to achieving sustainability objectives within economic, social and environmental dimensions according to industry expert opinion. Industry experts provide higher weights to the economic dimension as the most significant contributor to sustainability, and chicken performs higher in these economic terms as compared to the potato supply chain.

Alternative weighting schemes and a more comprehensive analysis by completing a 'what-if' analysis would see a shift in the results. Also, the relative importance of sustainability factors will tend to shift over time. This shift is becoming even more pronounced as governments and communities are seeking ways to reduce environmental burdens while maintaining or improving social benefits. A benchmarking methodology such as the one proposed here can help to more effectively manage these trade-offs.

Social investors, consumers and environmental organisations, customers and policy makers can use the developed framework of assessment to inform their decisions. The developed framework can be useful for policy makers to measure sustainability performance across various supply chains (major commodities and products). Focal companies within food supply chains such as food manufacturers and supermarket retailers may adopt this framework to assess the sustainability performance of their products and compare within the sector. Sustainability scorecard development, becoming more common in commercial products, can be enhanced by more effectively considering and integrating multiple dimensions and scores. The framework can be used to make relative comparison between various commodities, but most importantly can be applied for comparison of various methods of production (e.g. organic and conventional) for the same product or products produced by different supply chains (companies or retailers). If applied to a company level, the developed benchmarking framework could assist consumers to evaluate sustainability performance of equivalent product lines and inform their purchasing behaviour. Thus, strategic, tactical and operational considerations for a variety of stakeholders can be evaluated with the results of this sustainability methodology.

Since we construct and range indicators between 1 and 6 , where 6 is the desirable sustainability performance or sustainability target, we can say that the closer the overall sustainability score of the supply chain the closer the supply chain is conforming to sustainability objectives or targets. Potential users of the framework (such as policy makers and individual companies) can set the maximum score as a desired target for sustainability performance (either policy target or individual corporate performance target) and using the framework can measure how the supply chains are performing in accordance with set targets. The higher the score the closer the supply chain overall in achieving sustainability targets within the three dimensions: economic, social and environmental.

This framework concentrates on food products produced within boundaries of a nation, and therefore does not specifically address the concept of food miles or the impacts associated with imported goods. Food supply chains are becoming increasingly globalised, and the reflection of the environmental and social burdens associated with importing products from abroad could be incorporate through including specific indicators to reflect carbon emissions associated with all stages of the supply chain (agricultural production, food manufacturing, food wholesale [including food imported from abroad], food retail and food catering). 
Rating of sustainability indicators on 1-9 scale requires detailed expert knowledge on operations and impacts of specific supply chains. As different experts were used for two different supply chains, experts may be biased and their opinion may affect the final scores. In the current study we decided to place more weight on the opinion of product specialists, but equal or other combinations for distributing the weights of expert opinions may be utilised. Perhaps, in order for companies to improve the sustainability performance, which is often interpreted by organisational stakeholders, companies and policy makers need to incorporate stakeholders in determining relative weights of indicators. Integrating more experts from various stakeholder groups (not just industry) may provide more evidence of what types of tradeoffs are willing to be made. A broader perspective, incorporating additional stakeholders can be completed using the geometric weighting scheme proposed in this study. The relative importance of these various stakeholders will also need to be established. Finding common footing may actually occur. Further negotiation on weighting schemes with sensitivity analysis will allow for a more complete picture of supply chain sustainability.

AHP, with its advantages, does have certain disadvantages. Consideration of interdependent relationships amongst the factors can provide a more realistic assessment of the situation. Thus, more complex models such as ANP and multiple-methodological linkages to optimisation tools such as goal programming may be useful extensions to this approach and require further investigation.

In the monitoring of the supply chain we focused primarily on the forward logistics stages. Although reverse logistics in the food supply chain has not had as much investigation as other supply chains (e.g., food may be easily and environmentally disposed of through composting practices), the inclusion of reverse logistics stages may be useful to get a more complete picture of the food supply chain. It may be dependent on the type of food, e.g. less perishable foods such as processed foods, may be more conducive to reverse logistics planning. And it may also depend on the supply chain stage, e.g. reverse logistics is of growing importance to supermarkets (Kumar 2008).

Broader application, studies and developing better data acquisition systems and performance measurement systems in the future may address these limitations. We provide one of the few studies to actually benchmark entire supply chains. More importantly, however, the proposed methodology, along with the case example, provides a strong foundation upon which to build.

\section{Note}

1. To ensure a fair comparison, when one supply chain is missing a value for an indicator (Table 4), the corresponding value for the other supply chain is also set to 0 . This process only affects one indicator (employees per enterprise in the Agriculture stage). Including the original, non-zero value for this indicator would make the overall sustainability index higher for the chicken supply chain.

\section{References}

Ahmed, P.K. and Rafiq, M., 1998. Integrated benchmarking: a holistic examination of select techniques for benchmarking analysis. Benchmarking for Quality Management and Technology, 5 (3), 225-242.

Bai, C. and Sarkis, J., 2010. Integrating sustainability into supplier selection with grey system and rough set methodologies. International Journal of Production Economics, 124 (1), 252-264.

Barrett, H.R., et al., 1999. Globalisation and the changing networks of food supply: the importation of fresh horticultural produce from Kenya into the UK. Transactions of the Institute of British Geographers, 24 (2), 159-174.

Biffaward, 2005. Poultry UK: mass balance of the UK poultry industry. Available from: http://www.massbalance.org/projects/ $? \mathrm{p}=000292[$ Accessed 14 November 2006].

Boks, C. and Stevels, A., 2003. Theory and practice of environmental benchmarking in a major consumer electronics company. Benchmarking: An International Journal, 10 (2), 120-135.

Camp, R.C., 1995. Business Process Benchmarking. Milwaukee: ASCQ Quality Press.

495 Carlsson-Kanayama, A., Ekstrom, M.P., and Shanahan, H., 2003. Food and life cycle energy inputs: consequences of diet and ways to increase efficiency. Ecological Economics, 44 (2/3), 293-307.

Chan, F.T.S., 2003. Performance measurement in a supply chain. The International Journal of Advanced Manufacturing Technology, 21 (7), 534-548.

Collins, A. and Fairchild, R., 2007. Sustainable food consumption at a sub-national level: an ecological footprint, nutritional and economic analysis. Journal of Environmental Policy and Planning, 9 (1), 5-30.

Courville, S., 2003. Use of indicators to compare supply chains in the coffee industry. Greener Management International, 43 (】), 94-105. 
DEFRA (Department for Environment, Food and Rural Affairs), 2006. Food industry sustainability strategy. London: DEFRA Publication. Available from: http://www.defra.gov.uk/farm/policy/sustain/ fiss/index.htm [Accessed 23 November 2006].

Elkington, J., 1997. Cannibals with forks: the triple bottom line of 21st century business. Oxford: Capstone.

Fine, B., Heasman, M., and Wright, J., 1996. Consumption in the age of affluence: the world of food. London: Routledge.

Forman, E. and Peniwati, K., 1998. Aggregating individual judgements and priorities with the Analytic Hierarchy Process. European Journal of Operational Research, 108 (1), 165-169.

Fritz, M. and Schiefer, G., 2008. Food chain management for sustainable food system development: a European research agenda. Agribusiness, 2 (4), 440-452.

Garnett, T., 2003. Wise moves: exploring the relationships between food, transport and carbon dioxide. London: Transport 2000 Trust.

Gerbens-Leenes, P.W., Nonhebel, S., and Ivens, W.P.M.F., 2002. A method to determine land requirements relating to food consumption patterns. Agriculture, Ecosystems and Environment, 90 (1), 47-58.

Gunasekaran, A., Patel, C., and Tirtiroglu, E., 2001. Performance measures and metrics in a supply chain environment. International Journal of Operations and Production Management, 21 (1/2), 71-87.

Heller, M.C. and Keoleian, G.A., 2003. Assessing the sustainability of the US food system: a life cycle perspective. Agricultural Systems, 76 (3), 1007-1041.

Hervani, A.A., Helms, M.M., and Sarkis, J., 2005. Performance measurement for green supply chain management. Benchmarking: An International Journal, 12 (4), 330-353.

Hinrichs, C.C. and Lyson, T.A., 2008. Remaking the North American food system: strategies for sustainability. Lincoln, NE: University of Nebraska Press.

Hughes, A., 2001. Multi-stakeholder approaches to ethical trade: towards a reorganisation of UK retailers' global supply chains? Journal of Economic Geography, $\mathbf{\Pi}$ (1), 421-437.

Ilbery, B. and Maye, D., 2005. Food supply chains and sustainability: evidence from specialist food producers in the Scottish/ English borders. Land Use Policy, 22 (4), 331-344.

Ilbery, B. and Maye, D., 2007. Marketing sustainable food production in Europe: case study evident from two Dutch labelling schemes. Tijdschrift voor Economische en Sociale Geografie, 98 (4), 507-518.

Jayanthi, S., Kocha, B., and Sinha, K.K., 1999. Competitive analysis of manufacturing plants: an application to the U.S. processed food industry. European Journal of Operational Research, 118 (2), 217-234.

Kärnä, A. and Heiskanen, E., 1998. The challenge of 'product chain' thinking for products development and design - the example for electrical and electronic products. The Journal for Sustainable Product Design, (4), 26-36.

Kumar, S., 2008. A study of the supermarket industry and its growing logistics capabilities. International Journal of Retail \& Distribution Management, 36 (3), 192-211.

Linstead, O. and Ekins, P., 2001. Mass balance UK: mapping UK resource and material flows. Available from: http:// www.massbalance.org/files/uploaded/download.php?filename $=$ mass $\% 20$ balance $\% 20$ mapping $\% 20$ report.pdf [Accessed 14 November 2006].

Manning, L., Baines, R., and Chadd, S., 2008. Benchmarking the poultry meat supply chain. Benchmarking: An International Journal, 15 (2), 148-165.

Marsden, T., Murdoch, J., and Morgan, K., 1999. Sustainable agriculture, food supply chains and regional development: editorial introduction. International Planning Studies, \(4), 295-301.

McNair, C.J. and Leibfried, K.H.J., 1995. Benchmarking: a tool for continuous improvement. New York: Wiley.

Min, H. and Galle, W.P., 1996. Competitive benchmarking of fast-food restaurants using the Analytic Hierarchy Process and competitive gap analysis. Operations Management Review, 11 (2/3), 57-72.

545 New, S.J., 1997. The scope of supply chain management research. Supply Chain Management: An International Review, 2 (1), 15-22.

Oral, M., 1993. A methodology for competitiveness analysis and strategy formulation in glass industry. European Journal of Operational Research, 68 (1), 9-22.

Parkan, C., 1994. Operational competitiveness ratings of production units. Managerial and Decision Economics, 15 (3), 201-221.

Pretty, J.N., et al., 2005. Farm costs and food miles: an assessment of the full cost of the UK weekly food basket. Food Policy, 30 (6), 1-19.

Roth, A.V., et al., 2008. Unraveling the food supply chain: strategic insights from China and the (2007) recalls. Journal of Supply Chain Management, 44 (1), 22-39.

555 Saaty, T.L., 1980. The Analytic Hierarchy Process. New York: McGraw-Hill.

Saaty, T.L., 1996. Decision making with dependence and feedback: the analytic network process. Pittsburgh: RWS Publications.

Sarkis, J., 2001a. Benchmarking for agility. Benchmarking: An International Journal, 8 (2), 88-107.

Sarkis, J., 2001b. Manufacturing's role in corporate environmental sustainability - concerns for the new millennium. International Journal of Operations and Production Management, 21 (5-6), 666-686. 
Schvaneveldt, S.J., 2003. Environmental performance of products: benchmarks and tools for measuring improvement. Benchmarking: An International Journal, 10 (2), 136-151.

Seuring, S. and Müller, M., 2008. From a literature review to a conceptual framework for sustainable supply chain management. Journal of Cleaner Production, (16), 1699-1710.

Shepherd, C. and Günter, H., 2006. Measuring supply chain performance: current research and future directions. International Journal of Productivity and Performance Management, 55 (3-4), 242-258.

Simatupang, T.M. and Sridharan, R., 2004. Benchmarking supply chain collaborations: an empirical study. Benchmarking: An International Journal, 11 (5), 484-503.

Talluri, S. and Sarkis, J., 2001. A computational geometry approach for benchmarking. International Journal of Operations and Production Management, 21 (1-2), 210-223.

UN (United Nations), 1992. Agenda 21 - global programme of action for sustainable development, adopted by United Nations Conference on Environment and Development (UNCED), Rio de Janeiro, Brazil, 3-14 June. Availble from: http:// www.un.org/esa/sustdev/documents/ agenda21/index.htm [Accessed 5 May 2008].

UNCSD (United Nations Commission on Sustainable Development), 1998. Report E/CN. 17/1998/4 Industry and Sustainable Development. 6th session, New York, 13 April-1 May. Available from: http://www.un.org/esa/sustdev/sdissues/industry/ industry.htm [Accessed 11 November 2006].

Veleva, V., et al., 2003. Indicators for measuring environmental sustainability: a case study of the pharmaceutical industry. Benchmarking: An International Journal, 10 (2), 107-119.

Weatherell, C., Tregear, A., and Allinson, J., 2003. In search of the concerned consumer UK public perceptions of food, farming and buying local. Journal of Rural Studies, (19), 233-244.

Wever, R., et al., 2007. Increasing the benefits of product-level benchmarking for strategic eco-efficient decision making. Benchmarking: An International Journal, 14 (6), 711-727.

Yakovleva, N., 2007. Measuring the sustainability of the food supply chain: a case study of the UK. Journal of Environmental Policy and Planning, 9 (1), 75-100.

Yakovleva, N. and Flynn, A., 2004. Innovation and sustainability in the food system: a case of chicken production and consumption in the UK. Journal of Environmental Policy and Planning, 6 (3/4), 227-250.

Zairi, M. and Youssef, M.A., 1995a. Benchmarking critical factors for TQM: part I: theory and foundations. Benchmarking for Quality Management and Technology, 2 (1), 5-20.

Zairi, M. and Youssef, M.A., 1995b. A review of key publications on benchmarking: part I'. Benchmarking for Quality Management and Technology, 2 (1), 65-72.

Zairi, M. and Youssef, M.A., 1996. A review of key publications on benchmarking: part II. Benchmarking for Quality Management and Technology, 3 (1), 45-49.

Zhu, J., III. Quantitative models for performance evaluation and benchmarking. Berlin: Springer.

\section{Appendix A: questionnaire excerpt \\ Definitions:}

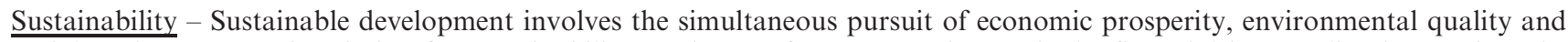
social equity. Companies aiming for sustainability need to perform not against a single, financial bottom line but against the triple bottom line.

600 Agriculture - includes processes that involve growing of plants (e.g. food crops, vegetables, fruit, etc) and crops combined with farming of animals; farming of birds and animals (poultry, cattle, sheep, goats, horses, asses, mules, hinnies and swine); and agricultural services activities.

Food processing - includes processes that involve production and preserving of meat, poultry (including slaughtering of birds and animals); processing and preserving fish and vegetables; manufacture of food products and drinks.

605 Food wholesale - includes processes that involve wholesale of agricultural raw materials, live birds and animals; wholesale of food, beverages and tobacco; and wholesale of grain, seeds and animal foods.

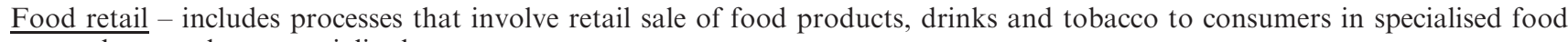
stores shops and non-specialised stores.

Food catering - includes processes that involve preparation and distribution of food products and drinks to consumers in hotels, hostels, camping sites, restaurants, cars and canteens.

Energy use - includes use of petrol, diesel, electricity, gas, etc.

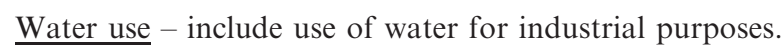

$\underline{\text { Waste }}$ - includes sewage and waste. 
Employment - provision of jobs including part-time, full-time, seasonal and permanent.

615 Wages - includes gross wages and salaries (in cash or kind).

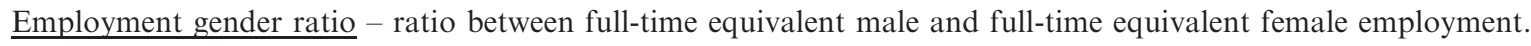

$\underline{\text { Productivity }}$ - is an indicator that measures the efficiency of the economy and could be measured by output per filled job.

Market concentration - concentration ratio for distribution is market share of total goods by largest enterprises.

Import dependency - is a share (\%) of imported goods in total volume of goods.

Questionnaire on comparative importance of sustainability indicators in the food supply chain

On a scale of one to nine please rate the significance of one issue over the other issue. Please mark with $\mathrm{X}$ one of the nine boxes provided for each answer.

\begin{tabular}{|c|c|c|c|c|c|c|c|c|c|c|}
\hline No. & Questions & 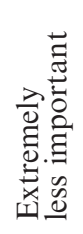 & 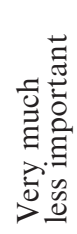 & 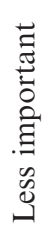 & 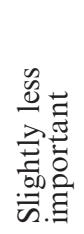 & 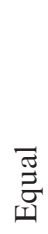 & 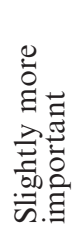 & 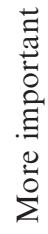 & 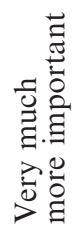 & 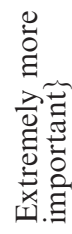 \\
\hline & & 1 & 2 & 3 & 4 & 5 & 6 & 7 & 8 & 9 \\
\hline
\end{tabular}

$1 \quad$ In terms of SUSTAINABILITY OF THE FOOD SUPPLY CHAIN

A How significant are environmental factors when compared to economic factors?

B How significant are environmental factors when compared to social factors?

C How significant are social factors when compared to economic factors?

2 In terms of their ENVIRONMENTAL IMPACT

A How much more important are agricultural activities when compared to food processing activities?

B How much more important are agricultural activities when compared to food wholesale activities?

C How much more important are agricultural activities when compared to food retail activities?

D How much more important are agricultural activities compared to food catering?

E How much more important are food processing activities when compared to food wholesale activities?

F How much more important are food processing activities when compared to food retail activities?

G How much more important are food processing activities when compared to food catering activities?

$\mathrm{H} \quad$ How much more important are food wholesale activities when compared to food retail activities?

I How much more important are food wholesale activities when compared to food catering activities? 
How much more important are food retail activities when compared to food catering activities?

3 In terms of their SOCIAL IMPACT

A How much more important are agricultural activities when compared to food processing activities?

B How much more important are agricultural activities when compared to food wholesale activities?

C How much more important are agricultural activities when compared to food retail activities?

D How much more important are agricultural activities compared to food catering?

E How much more important are food processing activities when compared to food wholesale activities? 